\title{
Gender Imbalance in Management Consulting Firms - A Story about the Construction and Effects of Organizational Identity
}

\author{
Matthias Tomenendal ${ }^{1, *} \&$ Cansu Boyoglu ${ }^{1}$ \\ ${ }^{1}$ Berlin School of Economics and Law, Badensche Str. 52, 10825 Berlin, Germany \\ * Corresponding author: Berlin School of Economics and Law, Badensche Str. 52, 10825 Berlin, Germany. E-mail: \\ matthias.tomenendal@hwr-berlin.de
}

Received: March 1, 2014

Accepted: March 24, 2014 Online Published: April 18, 2014

doi:10.5430/mos.v1n2p30

URL: http://dx.doi.org/10.5430/mos.v1n2p30

\begin{abstract}
Official statements by management consulting firms on the importance and benefits of gender balancing stand in contrast with remarkably imbalanced boards of those firms in Germany and subjective perceptions of individual employees about gender biased human resource practices. It can be assumed that there are deep level root causes of gender imbalances in consulting firms which are not easy to change and which touch upon questions of organizational identity. Exploring this topic from a specific angle - explaining gender imbalance in German consulting firms by processes of identity construction -, an innovative approach is taken: a fictitious story of a female consultant joining a large management consultancy in Germany is mirrored by general findings from social identity theory literature in order to derive conceptual, interpretative conclusions on root causes of gender imbalances on senior management levels of management consulting firms.
\end{abstract}

Keywords: gender imbalance; organizational identity; storytelling

\section{Introduction: What are Root Causes for Heavy Gender Imbalances in Consulting Firms' Top Management?}

In Europe, women account for more than 55 percent of university graduates, but they take only 14 percent of corporate board seats of the largest publicly listed companies (Eurostat, 2011, 2012). At the current rate of progress "it would take more than 40 years to arrive at gender balanced boards" (i.e. at least $40 \%$ of both sexes; European Commission/Directorate-General for Justice, 2012, p. 15). Several studies which compare men and women with the same background, qualifications, age, experience and time devoted to work state that women's success rates in progressing to the highest management levels are lower than those of their male counterparts (Devanna, 1987). In addition, and linked to the imbalance in hierarchical positions (Ely \& Meyerson, 2000; Ridgeway \& Smith-Lovin, 1999), gender is also making a difference in compensation (e.g., Blau \& Kahn, 1994).

In the management consulting industry the share of women among board members is even far below the already low average across all industries. In Germany, the share of female partners at McKinsey \& Co. amounts to 6\%, at Boston Consulting Group to approximately 9\% (including Austria), at Bain \& Co. to 4\% (including Switzerland) and at Roland Berger Strategy Consultants to 8\% (Töpper, 2012). This is astonishing as all of the named firms have published special websites or even studies about the general importance of gender balance, the most prominent of them probably being McKinsey \& Co.'s “Women Matter” report which states that organizations with a greater share of women at top levels deliver stronger organizational and financial results (McKinsey \& Company, 2007).

The general reasons for gender imbalance in top management positions have been discussed widely. Frequently analyzed phenomena are (1) the glass ceiling effect, i.e. invisible obstacles for women to ascend to higher hierarchical levels, based on traditional and cultural stereotypes (Morrison \& von Glienow, 1990); (2) the double burden syndrome, i.e. women's simultaneous responsibility for their professional careers and household tasks, often leading to part-time employment by women (Statistisches Bundesamt, 2010, pp. 33-34); (3) the lack of female role models and a deficient supporting lobby (Etienne, 2010); or (4) the lack of personal ambitions of women to pursue top management careers (Hewlett \& Buck Luce, 2005). 
While it seems that these phenomena are well documented, the root causes and meanings of them remain less clear. Phillips and Imhoff (1997, p. 57) state in this context: "There is far more recording of gender and gender role differences than there is exploring the meaning of these differences". Discussing the "meaning" goes to root causes of differences and touches upon questions like "Who am I?", "Who are we?", "What do we stand for?" and "What do we want to be?". These are typical identity questions, in particular questions of organizational identity. Thus, the link between questions of gender balance and (organizational) identity appears. It is well known that constructions of identity provide a logic for explaining gender imbalances in top management positions (Rosenblum, 2008), especially in leadership positions in the "professions" (Rubineau 2008), mainly due to the inability of women to balance personal and professional responsibilities which in turn leads to role conflicts (Hill, Leinbaugh, Bradley, \& Hazier, 2005). Empirical findings on this topic also indicate that "male participants may feel more empowered in the field, gravitate toward leadership positions or positions of status more readily, and receive more mentorship and encouragement in this direction.” (Healey \& Hays 2012, p. 59) Hence, men are supposed to be more inclined to successful professional identity development. The effect of professional identity development on gender imbalance specifically in German consulting firms has not been analyzed in detail yet. It is this research gap which our paper focuses on and where it aims to make a contribution.

\section{Methodology: Storytelling, Conceptualizing and Interpreting}

In order to set the stage, a short story will be told in the next section of our paper. It is a fictitious, but possibly true story of a female consultant entering a German management consulting firm. The story is meant to be illustrative of problems which young female consultants might encounter upon entering into large management consulting firms. The deployed method of storytelling is indebted to the "reformed" approach to social sciences (Polkinghorne, 2007, p. 473) which became popular after the "narrative turn" (Denzin, 1997) in the respective community. Stories give a "voice to those traditionally marginalized (...and provide) a more complex and complete picture of social life" (Hendry, 2007, p. 490). It does not replace analytical thinking but can be used among other methods in qualitative research on new ground (Kendall \& Kendall, 2012; Lewis, 2011), especially to foster change and innovation (Denning, 2000), two characteristics that management consulting firms in Germany could need for overcoming gender imbalances in their top management. Our story is used as a premise to ground the subsequent conceptual and interpretative argumentation of the paper. This argumentation is based on a review of basic literature on individual and organizational identity, identity construction and the respective link to gender balancing and a subsequent approach to mirror the story with key concepts from the literature. In the final section of the paper conclusive thoughts and limitations of the paper are presented.

\section{A Short Story: Susan is Joining a German Management Consulting Firm}

"Susan, a smart and successful business school graduate, wants to join a top international management consultancy that has a fabulous reputation, both as a desired employer by providing numerous benefits to its employees as well as by having the most prestigious clients. In addition, she is impressed by other people's stories and experiences ("Only the best and brightest people work there!”; "I have already advanced within three years!”; "You also get a chance to see the world!”; "I am earning more money than I can even spend!”), and thus chooses this particular consultancy as a prospective employer. After applying and 'surviving' the very selective entrance tests, a one-day assessment center and many solved case studies, she can proudly call herself a professional consultant with an office, her name on the door, a new briefcase, a new set of business cards, and the latest Blackberry.

As time passes by, Susan begins to realize that the type of work she is doing most of the time does not match her expectations about what she thought she would be doing. While expecting 'glamorous' consulting work at prestigious firms with high discretion on the projects, she finds herself doing standardized work at small no-name firms in the middle of nowhere. In addition, as most of her colleagues work long hours and often on weekends, she also works up to fifteen hours a day without complaining neither on the workload nor the work content. Of course, Susan knows that patience is a virtue that every consultant should have and just hopes that one day one of her project managers would recognize her hard work and patience. However, to her surprise, she receives feedback from her project manager that her work results and attitude do not match the firm's expectations and that she should work on her self-presentation, mainly during client interactions. Susan wonders how her project manager arrived at this conclusion, as he was rarely present on the project. Slowly but surely, this unknown feeling inside of her emerges that she must be doing something clearly wrong. 
Susan begins to have doubts not just about herself but about the firm, too. Unconsciously, she thinks about the time when she was a successful student, getting the best grades and how it felt not to be stressed all the time, having the freedom to spend time with family and friends. While being in a struggle with her ambivalent feelings ("Come on, this is what you wanted to be, have your career in mind"), she hears from her male colleagues that they get allocated on those long-term projects at prestigious firms, which she always hoped for. She knows that those high-revenue assignments are a significant key for advancement within the firm. While thinking about the possible reasons for this development, she begins to understand that the project managers, mostly men, are having frequent interactions with other male colleagues, e.g., lunches, coffee-breaks or even after-work activities as playing football, whereas she is always having her lunch with other female consultants. Up to that moment, she had never met any colleague outside of work and did not even see the need for this, as she does not like most of her colleagues for many reasons. Especially her male colleagues are acting in a macho-way, and it is hard not to feel their aggressive presence while they tell their never-ending stories about stupid or lazy clients. Just recently, she heard them making jokes about this year's promotions and bonuses, especially about one female senior consultant, who has been waiting for her promotion for six years and who did not get promoted again this year - 'every year the same procedure, at least it was clear to me that she would not get promoted to the manager level. She has two children, comes late to meetings or leaves earlier than anybody else. How could she possibly add value to the firm or even represent it? I wonder why she is still staying at this firm.' Upon hearing this, Susan also asks herself why she should stay at this firm when all the efforts and sacrifices she makes go unnoticed or even worse, when superiors criticize her and her work instead of helping her. She feels that talking with her family and friends could help her. They think however that these kinds of firms work that way, that they torment consultants mercilessly and that she either has to accept it or leave the firm. As her level of motivation is already low and she more than once acted as if she was sick, she decides to quit her job.”

\section{Literature Review: Identity Construction as a Theoretical Basis}

As a theoretical base for a conceptual and interpretative argumentation key findings from social identity theory are presented in this chapter. They constitute a specific lens through which to view Susan's story later.

\subsection{Social Identity Theory}

Despite a wealth of literature the term identity remains vaguely defined. Among the more pronounced conceptual approaches, social identity theory (SIT) by cognitive social psychologists Henry Tajfel and John Turner has introduced a concept of identity which is central to our understanding of how individuals or groups relate to their social environment (Tajfel, 1978). Based on that view, identity, "the location of an individual in social space" (Gecas, Thomas, \& Weigert, 1973, p. 477), has two components: a personal component derived from idiosyncratic characteristics, such as physical, personal, and intellectual characteristics, and a social component derived from group memberships, such as gender, nationality, race, social class, age, corporate belonging, and occupation (Ashforth \& Mael, 1989; Turner, 1982). Individuals may have multiple identities; the significance of group memberships depends on the situational relevance (Ashforth \& Mael, 1989).

Based on SIT the construction of the social component of identities derives from "an individual's knowledge of his or her memberships in social groups together with the emotional significance of that knowledge" (Turner \& Giles, 1981, p. 24). This process of identification involves categorization of the self and the social environment driven by an imperative for simplification and a need for self-esteem (Turner, 1982). Correspondingly, all human beings carry a basic tension within, which is to compare themselves to others, searching for common or similar attributes (social identity), and nevertheless, feeling the opposing necessity for individualism and uniqueness (personal identity).

Self-categorization theory (SCT), the cognitive dimension of social identity (Turner, 1985), is specified in terms of the causes and consequences of social categorization of the self and others. According to Hogg (2001), the process of social categorization segments the social environment into in-groups and out-groups that are represented as prototypes. "These prototypes are context specific, multidimensional fuzzy sets of attributes that define and prescribe attitudes, feelings, and behaviors that characterize one group and distinguish it from other groups“ (Hogg, 2001, p. 187). Individuals are more likely to identify with a social group that matches their own self-concept, and while joining the group, individuals de-personalize their own self-concept in favor of adopting more of the features of the group’s prototype (Hogg, 2001).

In fact, individuals may have as many social identities as they have group memberships (Tajfel \& Turner, 1979). Individuals may subscribe themselves to different social categories, labelling themselves with a plurality of 
characteristics and adapting different roles, e.g., one individual can be female, married, a loving mother, but also be a black, middle-class mid-forties manager with a passion for ballet at the same time. Being a "female" is one important aspect of a social identity as it gives meaning to one's own self-definition. Depending on the salience of comparative distinctions, identification with this category can either evoke positive, negative, or ambivalent feelings (Hogg \& Terry, 2000). These distinctions further affect an individual's self-attributions, including some stereotypic attributions. Assuming that being a female creates certain expectations to fulfil (e.g., giving birth), it is similar to a social role (Ashforth \& Mael, 1989), and thus, provides the individual with a guideline for how to behave, think and act (Hogg \& Terry, 2000). Many social categories provide individuals with templates or roles for decision-making and acting, and hence, with a sense of security in knowing how to behave and how not to behave. Ultimately, membership to a group gives a sense of identity and meaning to reality. A very important group in professional life is the organization which an individual belongs to.

With regard to the identity of organizations, most current publications and empirical studies are indebted to Albert and Whetten's (1985) view that an organization's identity is what is central, distinctive and enduring for the organization. The claimed enduring character of organizational identity has evoked criticism which has led to a more dynamic understanding of organizational identity recently: Now identities are understood as dynamic and contextual (Sveningsson \& Alvesson, 2003) rather than fixed and stable (Gioia, Schultz, \& Corley, 2000). In this respect, three key elements are supposed to shape the organizational identity: first, the organization's formal claims about what it is (any official statement as, for instance, the mission statement); second, the members' identity beliefs about the organization's central, distinctive, and enduring traits; and third, the identity aspirations (Lerpold, Ravasi, van Rekom, \& Soenen, 2007) or the "desired image" (Gioia \& Thomas, 1996) about the future identity (e.g., re-evaluating beliefs and values due to a change in strategy; Lerpold et al., 2007, pp. 6-8). In this way the organizational identity "provides institutional justification for organizational practices, routines, and policies, and provides the context within which members assign meaning to behaviour" (Lerpold et al., 2007, p. 4). Comparable to individuals, organizations try to maintain a balance between similarity and distinctiveness. In this context the beliefs of organization members seem to be more important than facts (Whetten \& Godfrey, 1998, p. 21).

\subsection{Organizational Identification}

Organizational identification, defined as the "(p)sychological linkage between the individual and the organization whereby the individual feels a deep, self-defining affective and cognitive bond with the organization as a social entity” (Edwards \& Peccei, 2007, p. 30), has been posited to lead to numerous benefits for individuals and organizations. First, members who strongly identify with their organizations can fulfil a variety of needs, including uncertainty reduction, safety, and a sense of belonging and self-esteem (e.g., Hogg \& Mullin, 1999; Pratt, 1998). Second, organizations with highly identifying members can also benefit from lower levels of turnover, increases in employee motivation, job satisfaction, and compliance (e.g., Cheney, 1983; Dutton, Dukerich, \& Harquail, 1994).

The extent to which members identify with their organization depends mainly on the attractiveness and distinctiveness of the organizational identity, and further on the perceived consistency between the self-identity and the organizational identity (Rindova \& Schultz, 1998, p. 51). The distinctiveness of the organizational identity is firstly derived from its differentiation from other relative organizations through images and symbols, and secondly, from the "construed external image“, i.e., what an organizational member believes outsiders think about the organization (Dutton \& Dukerich, 1991). If a member's identity contains the same characteristics as in the perceived organizational identity, the result will be a strong organizational identification, going so far that members would define the organization the same way as they would define themselves (Dutton et al., 1994, p. 239). Combined, these aspects can influence members' sense of self, both positively and negatively, and therefore, their behaviour and well-being (Dutton \& Dukerich, 1991; Dutton et al., 1994, p. 240).

When an organization has an attractive identity, e.g., characteristics associated with power, competence, virtue, or moral worth (Gecas, 1982), it will further enhance members' self-esteem as it helps them to create a more positive sense of self (Turner 1985) through seeing " $[\ldots]$ themselves with these positive qualities, strengthening the degree to which a member likes him- or herself” (Dutton et al., 1994, p. 247). Going further, "people may feel proud to belong to an organization that is believed to have socially valued characteristics. When members believe that outsiders see the organization in a positive light, they "bask in the reflected glory of the organization" (Cialdini, 1976, p. 366; cited from Dutton et al., 1994, p. 240).

In contrast, if members cannot identify with the organizational image, it may lead to "depression and stress" (Dutton et al., 1994, p. 240) and negatively valued organizational outcomes as increased competition among organizational members or an increase of members leaving the organization (Hirschman, 1970). Here, it is important to appreciate 
the fact that identities also have an "evaluative component" (Tajfel \& Turner, 1979), thus infusing identification with different types of emotions: positive, negative, and ambivalent (Pratt, 1998). Members can feel love (positive identification), hate (dis-identification), or feel conflicted (ambivalent identification) towards an organization. If an organization's actions do not align with its identity or when members contradict the organizational identity by their actions, this may lead to an interruption of organizational routines, "prompting individuals to ask, 'What is this organization really about?' These actions motivate members to review and acknowledge what they believe defines the organization, and this affects the strength of their connection to the organization“ (Dutton et al., 1994, p. 243).

\subsection{Identity Construction}

Identity can be seen as an ongoing social process by which individuals craft a sense of self (Giddens, 1991). Based on this, Giddens (1991, p. 53; italics in original) defines self-identity as "not a distinct trait, or even a collection of traits, possessed by the individual. It is the self as reflexively understood by the person." The construction of identities takes place in a complex social, cultural, and organizational context (Ashforth \& Mael 1989). Ybema, Keenoy, Oswick, Beverungen, Ellis, and Sabelis (2009, p. 303) regard identity formation as "processes of negotiation between social actors and institutions, between self and others, between inside and outside, between past and present." Micro approaches to identity construction analyze how the identities of organizational members are constructed by working in a given organizational context. Macro approaches on the other hand are more concerned with how collective conceptions of a given identity, e.g. gender identity, are constructed and shaped by organizations. In this paper both of those approaches will be taken into account, as the interplay between the macro and micro level is suggested to be of crucial importance.

Building on Giddens' definition of self-identity as a reflexively developed narrative of the self, Alvesson and Willmott (2002) provide a comprehensive discussion of how identity construction occurs in organizations. The authors have developed a three-part framework for understanding identity in relation to organizations, which includes self-identity, identity work, and identity regulation. The authors further argue that the social processes of identity work and identity regulation function together in shaping self-identities. Identity work is defined as "the ongoing mental activity that an individual undertakes in constructing an understanding of the self that is coherent, distinct and positively valued" (Alvesson, Lee Ashcraft, \& Thomas, 2008, p. 15), “aiming to achieve a feeling of a coherent and strong sense of self" (Alvesson \& Willmott, 2002). The body of literature on identity work illustrates processes that are actively driven by individuals as well as organizations. Wrzesniewski, Dutton, and Debebe (2003, p. 97) state that "(o)ur perspective assumes that employees actively compose work meaning by what they notice and how they interpret the actions of others at work...Our perspective imbues employees with a greater sense of agency and proactivity....”.

Alvesson and Willmott (2002, p. 625) define identity regulation as „,...] the more or less intentional effects of social practices upon processes of identity construction and reconstruction." According to the authors identity regulation is done through discursive tools and other mechanisms aimed at enjoining employees to construct identities "that are deemed congruent with managerially defined objectives” (Alvesson \& Willmott, 2002, p. 619). Control may be achieved through "the self positioning of employees within managerially inspired discourses about work and organization with which they may become more or less identified and committed" (Alvesson \& Willmott, 2002, p. 620). Common management and organization practices, e.g., hierarchies, rewards, leadership, and (gendered) divisions of labor are integrated with an individual's identity work and operate inside of the individual's quest for self-definition, coherence and meaning. The authors identify induction, training, and promotion procedures as particularly notable for influencing the identity work of employees (Alvesson \& Willmott, p. 625). Thus, the base of identification in organizations is laid in early phases of membership of employees.

Deetz (1995, p. 87) states that “the modern business of management is often managing the 'insides' - the hopes, fears and aspirations - of workers, rather than their behaviors directly". Kärreman and Alvesson (2004, p. 5) call this form of managerial control socio-ideological control, as it works on the beliefs and norms of members by targeting social relations and emotions. Pratt (2000, p. 464) describes the identity regulation activities undertaken by organizations, e.g., how the corporation Amway engages in "sense-breaking" activities to create a "meaning void" and motivate members to take on a new identity through the organization's sense giving practices.

\subsection{The Identity Customization Process}

Ibarra (1999, p. 765) states: "Despite consensus in the socialization literature that identity changes accompany work role changes, the process by which identity evolves remains under explained.” Pratt, Rockmann, and Kaufmann (2006) have helped to shed some first light on this complex process as they do not just focus on when an identity is going to change but particularly on how. During their longitudinal, qualitative study of medical residents during their 
first year at an elite graduate medical education center, the authors found that identities have different strategies to respond to sense-making processes, and depending on certain aspects that favour identity change, it is possible to predict the type of the emerging or customized identity. Even though their study focuses on how physicians are constructing their identities, the authors state that their findings are applicable to all professionals (Pratt et al., 2006, p. 258). The authors found that the process of identity construction is actively triggered by work-identity integrity violations through organizations: an experienced mismatch between whom one is ("being") and what one does (“doing”; Pratt et al., 2006, p. 253). This experienced mismatch leads to a need for constructing a new or customized identity as it "unfreezes" (Lewin, 1958; Schein, 1987) an individual's current sense of self (sense-breaking) and further leads to a "seeking" of identity-related meaning (sensemaking; Pratt et al., 2006, p. 254). These violations are then resolved through identity customization processes, where the outcome depends largely on the violation magnitude (minor or major), the level of job discretion (low or high) and the strength of the current identity. The organization is further able to limit the "raw materials" for customizing the identity (which members draw upon to make sense of their work; Pratt et al., 2006, p. 257) through limiting available identity sets, e.g., through encapsulating members to the organization by long working hours (Pratt et al., 2006, p. 248) and by influencing the social validation process via feedback and role models (Pratt et al., 2006, p. 250).

When the work-identity integrity violation is minor, then the sensemaking process will result in identity enrichment, or "a more nuanced understanding of the identity" (Pratt et al., 2006, p. 254). When the violation is major, there are two possible outcomes depending on the strength of the identity: if the identity is weak, i.e., individuals have no clear sense of who they are ("embryonic identity", defined as being "rudimentary and ineffective, analogous to the small clublike arms and legs of a young fetus"; Hall, 1968: 465; in Pratt et al., 2006), the outcome is identity splinting. In that case, individuals will temporarily adopt a previous social identity (e.g., student identity) to make sense of their work and to protect the growing professional identity (Pratt et al., 2006, p. 254). The authors state that this process is most likely to occur at the beginning of a professional career or through advancing in the career path and that it will stop when the fragile identity gets stronger through different work contents and processes or due to an increase in expertise.

If the identity is strong, a major violation will lead to a different type of customization: identity patching. This strategy helps members to interpret their work by simply adding new work-related aspects to their already strong identity, e.g., from the organizational culture (Pratt et al., 2006, p. 254). Furthermore, the authors stress the importance of social validation methods such as feedback systems and role models. Feedback systems play a vital role in shaping members' behaviors through ,,[...] learning what they, and others, were doing wrong and consequently how the work should be performed, they changed how they viewed themselves... " (Pratt et al., 2006, p. 251). In their study members chose role models that reflected themselves and helped them in "identity learning" (Ibarra, 1999) through validating their existing or emerging identities (Pratt et al., 2006, p. 255).

\subsection{Identity Construction and Gender Balance}

Gender can be defined as the "patterned, socially produced distinctions between female and male, feminine and masculine' (Acker, 1992, p. 250). In gender studies, the distinction between sex as a biological construct and gender as a social construct is widely accepted (Oakley, 1972). Gender is regarded as a product of socialization and experience (Unger, 1979). The terms "gender" or "gender identity" are used for characteristics that are socio-culturally considered appropriate for (mainly) males and females and hereby refer to the characteristics that are learned or developed rather than those that emerge from biological origins (Ridgeway \& Smith-Lovin, 1999; Unger, 1979).

In general, identities are heavily gendered as gender is a significant source of creating meaning around the self and thus influences an individual's self-definition and self-perception. Identities are partly developed in the context of power relations (Foucault, 1980, 1982; Knights \& Willmott, 1989), which set the standards for defining what is considered to be "normal" in society. From childhood on our perception of masculinities or femininities is formed through society and culture, e.g., through mass media, families, and friends, which in turn creates the individual desire to live up to those norms (Ely \& Padavic, 2007). Therefore, power also operates internally, expressed through the need to accept or resist such standards (Ely \& Padavic, 2007). Images of what is being accepted as masculine and feminine „,...] do not correspond to what most men and women are like, but nevertheless, a large number of people support and aspire to these ideals and are judged according to them" (Ely \& Padavic, 2007, p. 1129). Characteristics such as independence, control, aggression and rationality have traditionally been associated with men, while emotions, interdependence, empathy, vulnerability, and passivity are usually considered as feminine characteristics (e.g., Sjoberg \& Via, 2010; Gherardi, 1995; Kanter, 1977). Moreover, it is often argued that society and culture value 
these characteristics differently, which creates an asymmetrical power relation between the masculine and feminine. Patriarchal structures often dominate our society, privileging masculine values, or at least, what is considered as “manly" over feminine (Peterson, 2010, p. 18).

According to Meyerson and Kolb (2000, p. 563) „(o)rganizations as we know them are inherently gendered. Having been created largely by and for men, organizational systems, work practices, norms and definitions reflect masculine experience, masculine values, and men's life situations. This includes, for example, norms and assumptions in the work culture that value specific types of work and work processes, define competence and excellence of staff, and shape ideas about the best way to get work done." Acker (1990) further states that the interactions between men and women convey social exchanges that enact dominance and subordination, which together with socially constructed images, influence the gendered aspects of individual identity construction. As a result, women and men may seek, for instance, certain careers, a way of dress, or interaction styles at work. Hence, for individuals, as creators and followers, where theoretically both could make a change happen, identity construction processes form essential elements in the accomplishment of deconstructing divisions of labour and creating gender balance in organizations. How this can happen in management consulting firms is described in the following sections by applying key concepts from above to Susan's story.

\section{Identity Construction in a German Management Consulting Firm: Susan's Story of Her Unsuccessful Progress Mirrored by Extant Literature}

In the following section, the story of Susan, a fictitious female consultant in Germany is presented again and mirrored by excerpts from extant literature on identity in management consulting firms. For this purpose, the story will be deconstructed and analyzed in three parts which correspond to main value added steps of consulting firms the human resource related steps of recruitment, personnel development/promotion as well as project work. These three steps are central to a consulting firm's capacity to build competitive advantage with focus on their main asset, human resources: first, young graduates are targeted in large numbers to recruit a continuous flow of energetic and ambitious new consultants; secondly, project work is executed in a structured way which aims to satisfy the "client first"; thirdly, a strict personnel development and promotion process is implemented which offers career paths to high-performing consultants and brings the firm a cadre of emerging leaders who strive for excellence and growth (Domsch \& Hristozova, 2006; Richter et al., 2008; Tomenendal, 2010, pp. 70-78). We will therefore juxtapose situations from Susan's story which refer to the three key value-added steps of consultancies with messages and findings from social identity and social categorization theory in order to derive findings on a gendered identity construction.

\subsection{Recruitment and Identity Construction: "a Professional and Attractive Employer"}

"Susan, a smart and successful business school graduate, wants to join a top international management consultancy that has a fabulous reputation, both as a desired employer by providing numerous benefits to its employees as well as by having the most prestigious clients. In addition, she is impressed by other people's stories and experiences ("Only the best and brightest people work there!"; "I have already advanced within three years!"; "You also get a chance to see the world!"; "I am earning more money than I can even spend!"), and thus choses this particular consultancy as a prospective employer. After applying and 'surviving' the very selective entrance criteria, a one-day assessment center and many solved case studies, she can proudly call herself a professional consultant with an office, her name on the door, a new briefcase, a new set of business cards, and the latest Blackberry."

Recalling self-categorization theory, joining a social group is "actually transforming self-conception and assimilating all aspects of ones attitudes, feelings, and behaviors to the ingroup prototype“ (Hogg, 2001, p. 187). Hence, Susan chose the large management consulting firm as her employer because she perceived that the firm's characteristics and values matched her own self-concept. She perceived the company to be professional which meant for her - a top-performing student - to offer many opportunities in a meritocratic environment. Her self-identity seemed to match the organizational identity. The latter she derived from the firm's relative differentiation to other organizations through images and symbols and the construed external image, which she mainly got confronted with via current employees.

At this stage the identity construction is gendered only to a minor extent. For Susan this aspect did not play a major role. This finding is consistent with the fact that management consulting firms stress the importance of gender balance in their public statements: The image of a consultant's job for recruits is not heavily gendered. For male and 
female university graduates large management consulting firms qualify as professional and attractive employers.

\subsection{Project Work and Identity Construction: "Work Hard, Play Hard"}

"As time passes by, Susan begins to realize that the type of work she is doing most of the time does not match her expectations for what she thought she would be doing. While expecting 'glamorous' consulting work at prestigious firms with high discretion on the projects, she finds herself doing standardized work at small no-name firms in the middle of nowhere. In addition, as most of her colleagues work long hours and often on weekends, she also works up to fifteen hours a day without complaining neither on the workload nor the work content. (...)

Susan begins to have doubts not just about herself but about the firm too. Unconsciously, she thinks about the time when she was a successful student, getting the best grades and how it felt not to be stressed all the time, having the freedom to spend time with family and friends. While being in a struggle with her ambivalent feelings ("Come on, this is what you wanted to be, have your career in mind"), she hears from her male colleagues that they get allocated on those long-term projects at prestigious firms, which she always hoped for."

In an attempt to keep up the perceived elite status being part of an international management consulting firm, consultants work hard and strive to please their superiors, e.g. their project leaders and top managers. They usually accept all kinds of strenuous and long-lasting tasks. On the one hand this may surprise and even disappoint them with regard to the monotonous nature of the work, but on the other hand they stick to the tasks and even defend them as being glamorous vis-à-vis others. Within the firm it may be ambiguous how glamorous the own project work really is. Susan perceives her own tasks as not glamorous at all, and those of her (male) colleagues as quite glamorous. This assessment is however based on conversations with her colleagues and may be driven by their particular way of talking about their respective assignments.

The organizational identity of large management consultancies which is centered around elitism serves those companies to promote self-discipline and motivates the consultants to accomplish high standards of performance even when they might in fact be engaged in boring and repetitive work (Alvesson \& Robertson, 2006, p. 196). While the "discrepancy between the (elitist) self-understanding and expectations of the people recruited and some of the less inspiring tasks and work conditions offered (is) a source of tension" (Alvesson \& Robertson, 2006, p. 211) in consultancies, the notion of an elite identity which is also constantly communicated to the outside helps to keep up the morale of the employed consultants. Thus, a strong performance orientation is maintained within these consulting firms. Consultants report to work "about 60-70 hours per week and sometimes more", and they explicitly report that they strive "to prove their worth to the firm" (Alvesson \& Robertson, 2006, p. 211). The shared meanings, beliefs, values and symbols generate a "normative control” for consultants „naturally working hard, collaboratively and performing well in order to sustain their sense of self and organizational identity highlighting the dynamic interplay between project work and identity work“ (Alvesson \& Robertson, 2006, p. 219).

As a compensation for the hard work, next to career prospects, frequent and sometimes hilarious social events are organized by the consulting firms. It is well known that management consultancies are characterized by a “work-hard-play-hard”-culture (Deal \& Kennedy, 1987, p. 151). A life of extremes which may absorb complete personalities is regarded as typical of young management consultants and is an element of the constructed organizational identity. It becomes another element of the perceived superiority of the professional identity. "A construction of self and the organization as superior in vital respects are (...) important resources on which to draw to promote and reinforce the required self-confidence.“ (Alvesson \& Robertson, 2006, p. 211).

The continuous demonstration of self-confidence can rather be understood as a male than a female characteristic. This also holds true for demonstrating an overly self-confident attitude which is congruent with the "work-hard-play-hard"-culture of consultancies. It is thus plausible that the identity construction of consulting firms entails such elements as well, i.e. the notion that a distinctive characteristic of a consultant is a mixture of hard work and demonstrating that one takes everything in strike by "partying hard". Working extremely long hours is celebrated by individual consultants along with "tricks" how to cope with friends and partners when these might expect them at home. As it is obvious to everyone that the "client comes first", all client-driven appointments and changes to schedules are considered as a first priority. Consulting project leaders who do not necessarily put emphasis on being at home at a certain point of time in the afternoon or evening may celebrate open-end project meetings in the afternoon or be inclined to plan for long working hours of the entire team on short notice, thus serving the client in surprisingly and admirably short time spans. Being constantly available and working hard for long hours becomes a core competence of consultants and part of the identity construction which may thus be gendered, working in favor 
of male consultants.

The demographic composition of an organization influences the identity construction process as it sets the standard for role-related expectations, and based on these, the criteria for being successful or not. Susan did not match the role-related expectations about her, potentially because these were derived from the numerical dominance of men, and thus were rather masculine. As Susan started to work, she strived to convey images that conform to prototypic characteristics of this role (Ibarra, 1999). The way she acted and worked (working hard without complaining) can be seen as an attempt to signal the competence that would win approval from members of their role-set (Goffman, 1956). Soon Susan rejected however to incorporate the firm's values and practices. She rather engaged in dis-identification towards the firm, experiencing identity splinting when thinking about her student's life.

\subsection{Promotion and Identity Construction: "When the Going Gets Tough, the Tough Get Going”}

“(.. T)o her surprise, she receives feedback from her project manager that her work results and attitude do not match the firm's expectations and that she should work on her self-presentation, mainly during client interactions. Susan wonders how her project manager arrived at this conclusion, as he was rarely present on the project.(...)

She knows that (...) high-revenue assignments are a significant key for advancement within the firm. While thinking about the possible reasons for this development, she begins to understand that the project managers, mostly men, are having frequent interactions with other male colleagues, e.g., lunches, coffee-breaks or even after-work activities as playing football, whereas she is always having her lunch with other female consultants. Up to that moment, she had never met any colleague outside of work and did not even see the need for this, as she does not like most of her colleagues for many reasons. Especially her male colleagues are acting in a macho-way, and it is hard not to feel their aggressive presence while they tell their never-ending stories about stupid or lazy clients. Just recently, she heard them making jokes about this year's promotions and bonuses, especially about one female senior consultant, who has been waiting for her promotion for six years and who did not get promoted again this year - 'every year the same procedure, at least it was clear to me that she would not get promoted to the manager level. She has two children, comes late to meetings or leaves earlier than anybody else. How could she possibly add value to the firm or even represent it? I wonder why she is still staying at this firm.' Upon hearing this, Susan also asks herself why she should stay at this firm when all the efforts and sacrifices she makes go unnoticed or even worse, when superiors criticize her and her work instead of helping her. She feels that talking with her family and friends could help her. They think however that these kinds of firms work that way, that they torment consultants mercilessly and that she either has to accept it or leave the firm. As her level of motivation is already low and she more than once acted as if she was sick, she decides to quit her job”.

After having observed a meeting about promotions in a consulting firm, Alvesson and Kärreman (2007, p. 716) state that "to some extent conflicting criteria for promotion are being used, e.g., historical rating, experience... loyalty with the 'cash-cow project', client interaction, selling skills,... but also more metaphorical qualities like 'heavy and sharp'." "Interestingly, the highly formalized character of the feedback seems to devalue its effects. Superiors often do not have time to do it properly. Part of the problem is that it is difficult to provide rich feedback because this may call for careful monitoring, excellent judgment, language skills, and the allocation of considerable time.” (Alvesson \& Kärreman, 2007, p. 715)

Promotion decisions are usually being taken by committees of more senior consultants and heavily influenced by those superiors who have direct working relationships with or indirect knowledge of the consultants. In a typical pyramid structure of consultancies (Tomenendal, 2010, p. 70) those consultants who serve their superiors well in support of their own successful careers seem to have the best chances to be promoted. Again, flexible availability and additional effort are highly valued. Besides that a certain core competence or expert status helps career progression. The latter is also a question of the image of the individual consultant within the firm. "Political aspects also matter in... the tactic of junior people 'teaming up' with a senior person as a way of surviving in the firm“ and „(c)oalitions and personal interests generally play a role in assessments, promotions, and task assignments. Senior people want to have discretion and be able to make decisions based on their personal interests and preferences (e.g., on who to work with) without being constrained by aggregates of previous assessments” (Alvesson \& Kärreman, 2007, p. 716.).

Many of the decisive factors for promotion decisions are working in favor of male consultants: they are dominating in numbers, and at the current understanding of responsibilities for taking care of households and family lives in 
Germany, women are generally considered to be more inclined to refuse a permanent availability and permanent demonstration of own strengths.

\section{Conclusion: Gender Imbalance Caused by Identity Construction!?}

After an introduction into social identity theory and social categorization theory we have regarded Susan's fictitious story through the lens of some of the introduced concepts. This narrative exploration leads to one possible interpretation of Susan's situation which is surely not the only one. It is however very illustrative and is suited to generate more general hypotheses. Subsequently these would need to be formulated in the course of a model and then tested with empirical data. We encourage scholars to take these next steps in researching the introduced phenomena.

From our interpretation of the story we conclude that the mechanisms of identity construction which are currently in place in large international management consulting firms in Germany support gender imbalanced top management levels. This is mainly due to the emerging characteristics of the success identities in consulting firms which entail factors like hard work, demonstrated self-confidence, unconditional timely availability and flexibility, a certain degree of "toughness" and a strong effort of networking with similar colleagues on these dimensions. Most of these factors are gendered in practice, which means they become salient as different between genders, and male consultants benefit from them. This may be driven by the fact that the leaders of the firm are mainly male and that the typical business model of consultancies makes it difficult for consultants to succeed who need to follow strict timely arrangements outside the firm, such as holding schedules for family responsibilities. As the latter is in the majority of families in Germany rather a responsibility of women, career prospects for female consultants are lowered, which becomes part of the organizational success identity of the consulting firms.

We hypothesize that the further consultants climb the career ladder the more gendered their development prospects are: While the recruiting phase is hardly gendered - the large consulting firms look for a large number of recruits to hire - the project execution and personnel development phases show considerable gender aspects in identity construction. In these phases it becomes more important for a consultant to exert "toughness" and to spend a lot of time on the job for maximum effectiveness. This corresponds to a phase in life when women are inclined to give way to other identity elements such as caring mothers or the "moderators" of families and social networks.

We recommend that consulting firms deconstruct their management practices with regard to potential gender biases. In this respect they should reflect upon questions of organizational identity and their effects on gender balancing such as: Which central and distinctive patterns in the firm's personnel development processes and promotion decisions are potentially biased? How do role models react on clearly discriminating remarks and actions by colleagues? How do key stakeholders of the consulting firms like clients as well as friends and families of consultants (potentially indirectly) contribute to gender biased practices? Clear aspirations in this context will impact the ongoing identity construction processes in management consulting firms and will finally have an effect on the gender balance on senior management levels of those firms.

\section{References}

Acker, J. (1990). Hierarchies, jobs, bodies: a theory of gendered organizations. Gender \& Society, 4(2), 139-158. http://dx.doi.org/10.1177/089124390004002002

Acker, J. (1992). Gendering organizational theory. In: Mills, A. J. \& Tancred, P. (Eds.), Gendering organizational analysis (pp. 248-260). Newbury Park, CA: Sage.

Albert, S., \& Whetten, D. (1985). Organizational identity. In: Cummings, L. L., \& Staw, B. M. (Eds.), Research in Organizational Behaviour (Vol. 7, pp. 263-295). Greenwich: JAI Press.

Alvesson, M., \& Kärreman, D. (2007). Unraveling HRM: Identity, Ceremony, and Control in a Management Consulting Firm. Organization Science, 18(4), 711-723. http://dx.doi.org/10.1287/orsc.1070.0267

Alvesson, M., Lee Ashcraft, K., \& Thomas, R. (2008). Identity Matters: Reflections on the Construction of Identity Scholarship in Organization Studies. Organization, 15(1), 5-28. http://dx.doi.org/10.1177/1350508407084426

Ashforth, B., \& Mael, F. (1989). Social identity theory and the organization. Academy of Management Review, 14, 20-39. 
Alvesson, M., \& Robertson, M. (2006). The Best and the Brightest: The Construction, Significance and Effects of Elite Identities in Consulting Firms. Organization, 13(2), 195-224. http://dx.doi.org/10.1177/1350508406061674

Alvesson, M., \& Willmott, H. (2002). Identity Regulation as Organizational Control: Producing the Appropriate Individual. Journal of Management Studies, 39(5), 619-644. http://dx.doi.org/10.1111/1467-6486.00305

Blau, F. D., \& Kahn, L. M. (1994). Rising wage inequality and the U.S. gender gap. American Economic Review, 84, 23-29.

Cheney, G. (1983). On the Various and Changing Meanings of Organizational Membership: A Field Study of Organizational Identification. Communication Monographs 50, 342-362. http://dx.doi.org/10.1080/03637758309390174

Deal, T., \& Kennedy, A. (1987). Unternehmenserfolg durch Unternehmenskultur. Bonn-Bad Godesberg: Rentrop.

Deetz, S. (1995). Transforming communication, transforming business: building responsive and responsible workplaces. Cresskill, N.J: Hampton Press.

Denning, S. (2000). The Springboard: How Storytelling Ignites Action in Knowledge-Era Organizations, Butterworth-Heinemann. Woburn, MA: Butterworth-Heinemann.

Denzin, N. K. (1997). Interpretive ethnography: Ethnographic practices for the 21st century. Thousand Oaks, CA: Sage.

Devanna, M. A. (1987). Women in Management: Progress and Promise. Human Resource Management, 26(4), 469-481. http://dx.doi.org/10.1002/hrm.3930260404

Domsch, M. E., \& Hristozova, E. (2006). The Role of Human Resource Management in Consulting Firms. In: Domsch, M.E., \& Hristozova, E. (Eds.), Human Resource Management in Consulting Firms (pp. 3-18). Berlin Heidelberg New York: Springer. http://dx.doi.org/10.1007/3-540-31138-6

Dutton, J., \& Dukerich, J. (1991). Keeping an eye on the mirror: Image and identity in organizational adaptation. Academy of Management Journal, 34, 517-554. http://dx.doi.org/10.2307/256405

Dutton, J., Dukerich, J., \& Harquail, C. (1994). Organizational images and member identification. Administrative Science Quarterly 43, 293-327.

Edwards, M. R., \& Peccei, R. (2007). Organizational identification: development and testing of a conceptually grounded measure. European Journal of Work and Organizational Psychology, 16, 25-57. http://dx.doi.org/10.1080/13594320601088195

Ely, R. J., \& Meyerson, D. E. (2000). Theories of gender in organizations: A new approach to organizational analysis and change. Research in Organizational Behavior, 22, 103-151. http://dx.doi.org/10.1016/S0191-3085(00)22004-2

Ely, R., \& Padavic, I. (2007). A Feminist Analysis of Organizational Research on Sex Differences. Academy of Management Review, 32(4), 1121-1143. http://dx.doi.org/10.5465/AMR.2007.26585842

Etienne, M. (2010). Frauen in Aufsichtsgremien - talentierte Frauen sichtbar machen. In: Ritz, A., \& Thom, N. (Eds.) “Talent Management”, Wiesbaden: Gabler. http://dx.doi.org/10.1007/978-3-8349-8584-2_9

European Commission \& Directorate-General for Justice (2012). Women in economic decision-making in the EU: progress report. A Europe 2020 Initiative, Luxembourg.

Eurostat (2011). Share of women among tertiary students in Europe. Retrieved July 20, 2013, from http://epp.eurostat.ec.europa.eu/ᄀtgm/table.do?tab=table\&init=1\&plugin=1\&language=en\&pcode=tps00063

Eurostat (2012). Employment statistics in Europe. Retrieved July 20, 2013, from http://epp.eurostat.ec.europa.eu/statistics_explained/ᄀindex.php/Employment_statistics

Foucault, M. (1980). Power/knowledge: selected interviews and other writings, 1972-1977 (1st American ed.). New York: Pantheon.

Foucault, M. (1982). The subject and power. Critical Inquiry, 8, 777-795. http://dx.doi.org/10.1086/448181

Gecas, V. (1982). The self concept. Annual Review of Sociology, 8, 1-33. http://dx.doi.org/10.1146/annurev.so.08.080182.000245

Gecas, V., Thomas, D. L., \& Weigert, A. J. (1973). Social identities in Anglo and Latin adolescents. Social Forces, 
$51,477-484$.

Gherardi, S. (1995). Gender, symbolism and organizational cultures. London, Thousand Oaks, CA: Sage.

Giddens, A. (1991). Modernity and self-identity: self and society in the late modern age. Stanford, CA: Stanford University Press.

Gioia, D. A., Schultz, M., \& Corley, K. G. (2000). Organizational identity, image, and adaptive instability. Academy of Management Review, 25, 63-81.

Gioia, D. A., \& Thomas, J. B. (1996). Identity, image and issue interpretation: Sensemaking during strategic change in academia. Administrative Science Quarterly, 41, 370-403. http://dx.doi.org/10.2307/2393936

Goffman, E. (1956). The Presentation of Self in Everyday Life. Edinburgh: University of Edinburgh.

Healey, A. C., \& Hays, D. G. (2012). A Discriminant Analysis of Gender and Counselor Professional Identity Development. Journal of Counseling \& Development, 90, 55-62. http://dx.doi.org/10.1111/j.1556-6676.2012.00008.x

Hendry, P. M. (2007). The future of narrative. Qualitative Inquiry, 13, 487-498. http://dx.doi.org/10.1177/1077800406297673

Hewlett, S. A., \& Buck Luce, C. (2005). Off-Ramps and On-Ramps. Keeping Talented Women on the Road to Success. Harvard Business Review, March, 43-54.

Hill, N. R., Leinbaugh, T., Bradley, C., \& Hazier, R. (2005). Female counselor educators: Encouraging and discouraging factors in academia. Journal of Counseling \& Development, 83, 374-380. http://dx.doi.org/10.1002/j.1556-6678.2005.tb00358.x

Hirschman, A. O. (1970). Exit, voice, and loyalty: responses to decline in firms, organizations, and states. Cambridge, Mass: Harvard University Press.

Hogg, M. A. (2001). Social categorization, depersonalization, and group behaviour. In: Hogg, M. A., \& Tindale, R. S. (Eds.), Blackwell handbook of social psychology: Group processes (pp. 56-85). Oxford: Blackwell. http://dx.doi.org/10.1002/9780470998458

Hogg, M. A., \& Mullin, B. A. (1999). Joining groups to reduce uncertainty: Subjective uncertainty reduction and group identification. In: Abrams, D., \& Hogg, M. A. (Eds.), Social identity and social cognition (pp. 249-279). Oxford: Blackwell.

Hogg, M. A., \& Terry, D. J. (2000). Social identity and self-categorization processes in organizational contexts. Academy of Management Review, 25, 79-97.

Ibarra, H. (1999). Provisional Selves: Experimenting with Image and Identity in Professional Adaptation. Administrative Science Quarterly, 44(4), 764. http://dx.doi.org/10.2307/2667055

Kärreman, D., \& Alvesson, M. (2004). Cages in Tandem: Management Control, Social Identity, and Identification in a Knowledge-Intensive Firm. Organization, 11(1), 149-175. http://dx.doi.org/10.1177/1350508404039662

Kanter, R. M. (1977). Men and women of the corporation. New York: Basic Books.

Kendall, J. E., \& Kendall, K. E. (2012). Storytelling as a qualitative method for IS research: heralding the heroic and echoing the mythic. Australasian Journal of Information Systems, 17(2), 161-187.

Knights, D., \& Willmott, H. (1989). Power and Subjectivity at Work: From Degradation to Subjugation in Social Relations. Sociology, 23(4), 535-558. http://dx.doi.org/10.1177/0038038589023004003

Lerpold, L., Ravasi, D., van Rekom, J., \& Soenen, G. (2007). Introduction. In: Lerpold, L., Ravasi, D., van Rekom, J., \& Soenen, G. (Eds.), Organizational identity in practice (pp. 1-11). London, New York: Routledge. http://dx.doi.org/10.4324/NOE0415398398.ch0

Lewin, K. (1958). Group decision and social change. In: Newcomb, T. M., \& Hartley, E. L. (Eds.), Readings in social psychology (pp. 201-216). New York: Harper \& Row.

Lewis, P.J. (2011). Storytelling as Research/Research as Storytelling. Qualitative Inquiry, 17(6), 505-510. http://dx.doi.org/10.1177/1077800411409883

McKinsey \& Co. (2007). Women Matter. Gender diversity, a corporate performance driver. Retrieved July 24, 2013, from http://www.mckinsey.de/sites/mck_files/files/Women_Matter_1_brochure.pdf 
Meyerson, D. E., \& Kolb, D. (2000). Moving out of the armchair: Developing a framework to bridge the gap between feminist theory and practice. Organization, 7(4), 553-571. http://dx.doi.org/10.1177/135050840074003

Morrison, A. M., \& von Glienow, M. A. (1990). Women and Minorities in Management. American Psychologist, 45(2), 200-208. http://dx.doi.org/10.1037/0003-066X.45.2.200

Oakley, A. (1972). Sex, gender and society. London: Maurice Temple Smith.

Peterson, S. V. (2010). Gendered identities, ideologies, and practices in the context of war and militarism. In: Sjoberg, L., \& Via, S. (Eds.), Gender, War and Militarism: Feminist Perspectives (pp. 17-41). Santa Barbara, CA: Praeger.

Phillips, S. D., \& Imhoff, A. R. (1997). Women and career development: a decade of research. Annual review of psychology, 48, 31-59. http://dx.doi.org/10.1146/annurev.psych.48.1.31

Polkinghorne, D. E. (2007). Validity issues in narrative research. Qualitative Inquiry, 13, 471-486. http://dx.doi.org/10.1177/1077800406297670

Pratt, M. G. (1998). To be or not to be: Central questions in organizational identification. In: Godfrey, P (Ed.), Identity in organizations: Developing theory through conversations (pp. 171-207). Thousand Oaks, CA: Sage. http://dx.doi.org/10.4135/9781452231495.n6

Pratt, M. G. (2000). The good, the bad, and the ambivalent: Managing identification among Amway distributors. Administrative Science Quarterly, 45, 456-493. http://dx.doi.org/10.2307/2667106

Pratt, M. G., Rockmann, K. W., \& Kaufmann, J. B. (2006). Constructing professional identity: The role of work and identity learning cycles in the customization of identity among medical residents. Academy of Management Journal, 49, 235-262. http://dx.doi.org/10.5465/AMJ.2006.20786060

Richter, A., Dickmann, M., \& Graubner, M. (2008). Patterns of human resource management in consulting firms. Personnel Review, 37(2), 184-202. http://dx.doi.org/10.1108/00483480810850533

Ridgeway, C. L., \& Smith-Lovin, L. (1999). The Gender System and Interaction. Annual Review of Sociology, 25(1), 191-216. http://dx.doi.org/10.1146/annurev.soc.25.1.191

Rindova, V., \& Schultz, M. (1998). Identity within and without: Lessons from corporate and organizational identity. In: Whetten, D., \& Godfrey, P. (Eds.), Identity in Organizations: Developing Theory through Conversation (pp. 46-52). Thousand Oaks, CA: Sage.

Rosenblum, D. (2008). Loving gender balance: Reframing identity-based inequality remedies. Fordham Law Review, 76(6), 2873-2893.

Rubineau, B. A. (2008). Gendering professions: An analysis of peer effects. Retrieved January 15, 2014, from http://search.ebscohost.com/login.aspx?direct=true\&db=psyh\&AN=2008-99031-165\&site=ehost-live

Schein, E. (1987). Process consultation, Vol. 2: Lessons for managers and consultants. Reading, MA: Addison-Wesley.

Sjoberg, L., \& Via, S. (2010). Gender, war, and militarism: feminist perspectives. Santa Barbara, CA: Praeger.

Statistisches Bundesamt. (2010). Frauen und Männer in verschiedenen Lebensphasen. Wiesbaden.

Sveningsson, S., \& Alvesson, M. (2003). Managing Managerial Identities: Organizational Fragmentation, Discourse and Identity Struggle. Human Relations, 56(10), 1163-1193. http://dx.doi.org/10.1177/00187267035610001

Tajfel, H. (1978). Differentiation between social groups: studies in the social psychology of intergroup relations, London, New York: Published in cooperation with European Association of Experimental Social Psychology by Academic Press.

Tajfel, H., \& Turner, J. C. (1979). An integrative theory of intergroup conflict. In: Austin, W. G., \& Worchel, S. (Eds.). The social psychology of intergroup relations (pp. 33-47). Monterey, CA: Brooks/Cole.

Töpper, V. (2012). Miese Frauenquote in Unternehmensberatungen. Retrieved August 3, 2013, from http://www.spiegel.de/karriere/berufsleben/miese-frauenquote-in-unternehmensberatungen-a-822588.html

Tomenendal, M. (2010). Principles of Consulting. Aachen: Shaker.

Turner, J. C. (1982). Towards a cognitive redefinition of the social group. In: Tajfel, H. (Ed.). Social identity and intergroup relations (pp- 15-40). Cambridge: Cambridge University Press. 
Turner, J. C. (1985). Social categorization and the self-concept: A social cognitive theory of group behaviour. In: Lawler, E.J. (Ed.), Advances in group processes: Theory and research (Vol. 2, pp. 77-122). Greenwich, CT: JAI Press.

Turner, J. C., \& Giles, H. (1981). Intergroup behaviour. Oxford: Basil Blackwell.

Unger, R. K. (1979). Toward a redefinition of sex and gender. American Psychologist, 34(11), 1085-1094. http://dx.doi.org/10.1037/0003-066X.34.11.1085

Whetten, D. A., \& Godfrey, P. C. (1998). Identity in organizations: building theory through conversations. Thousand Oaks, CA: Sage.

Wrzesniewski, A., Dutton, J. E., \& Debebe, G. (2003). Interpersonal sensemaking and the meaning of work. In: Kramer, R. M., \& Staw, B. M. (Eds.), Research in Organizational Behavior (Vol. 25, pp. 93-135). Oxford: Elsevier.

Ybema, S., Keenoy, T., Oswick, C., Beverungen, A., Ellis, N., \& Sabelis. I. (2009). Articulating identities. Human Relations, 62(3), 299-322. http://dx.doi.org/10.1177/0018726708101904 